\title{
Cesta k reformě školy: Historicko-systematický pohled na prríkladu meziválečné pedagogické diskuse ${ }^{1}$
}

\section{TOMÁš KASPER}

V následujícím příspěvku bych se velmi rád pozastavil nad několika rovinami diskuse o školské reformě, která zaměstnává jak historicko-pedagogickou reflexi vzdělávání a výchovy, tak i aktuální pedagogické snahy a školskou politiku. Téma školské reformy zaujímá $\mathrm{v}$ současné pedagogické diskusi, ale i v diskusi 19. a 20. století zásadní postavení a zdá se, že je tématem tzv. věčným. Jak poukazují mnohé historicko-pedagogické studie, je téma školské reformy stejně staré jako moderní školská instituce sama. Studie upozorňují, že očekávání odborné i širší veřejnosti na adresu školy byla a stále jsou často tak vysoká (idealisticky nastavená), že škole nezbývá nic jiného než tyto představy zklamat a nenaplnit. To však nevedlo a nevede k revidování daných očekávání a funkcí a $\mathrm{k}$ jejich redefinování. Proto se moderní školská instituce dostává do soukolí reformních představ a požadavků, do permanentní školské reformy.

Zatímco do druhé světové války byla realizace školské reformy doménou zejména národních států, přestože reformně-peda- gogická diskuse byla mezinárodně otevřená a tzv. reformně-školský ruch nesl znaky světového hnutí (NEF), po roce 1945 se reforma školy stala jednou $\mathrm{z}$ oblastí soupeření rozděleného světa a po pádu berlínské zdi pak součástí diskuse o fungování, směřování globalizovaného světa. Mezinárodní šetření a měření výsledků vzdělávání v mezinárodním srovnávání, definování evropských vzdělávacích strategií a tlak globalizace na změnu pohledu na význam a roli vzdělávání a výchovy charakterizují současné rozvrstvení diskuse o reformě školství, vzdělávání a výchovy, z níž se nelze vymanit ani $\mathrm{v}$ př́padě koncipování vzdělávacích strategií v České republice. Ve svém příspěvku se pokusím o systematicko-pedagogické porovnání reformně-školských snah v meziválečném Československu a v současné diskusi. Budu mít na mysli připravovanou Strategii vzdélávací politiky $\check{C} R$ do roku 2030+ (dále Strategie 2030).

Proč se $\mathrm{k}$ tomuto srovnání odvažuji? Vede mne k tomu jistá historická analogie současné situace se společenskou situací

\footnotetext{
${ }^{1}$ Článek je referátem předneseným na konferenci ČAPV Pedagogický výzkum, školní praxe a výzvy demokracie na FP TU v Liberci dne 12. záŕí 2019. Článek vychází z publikovaných výstupů základního výzkumu, zejména Kasper, Kasperová \& Pánková (2018); Kasper \& Kasperová (v tisku).
} 
v meziválečném období. Dovolím si jistým způsobem porovnat dvacet let svobodné demokratické diskuse o podobě reformy školy v meziválečném Československu se zkušeností třiceti let svobodné a demokratické diskuse polistopadové České republiky, jak se odráží a jistým způsobem i završuje při definování vzdělávací Strategie 2030. Ta se utvárí na pozadí definování, realizace i „nerealizace“ dřívějších strategických dokumentů vzdělávací politiky, zejména tzv. Bílé knihy a Strategie 2020. I když zcela jistě není možné dvakrát vstoupit do stejné řeky, nebot' společensko-politické požadavky na procesy vzdělávání a výchovy jsou tehdy a dnes značně odlišné, je možné poukázat na prostředky, nástroje, aktéry reformy školy demokratické meziválečné reformně-školské diskuse, upozornit na jejich význam v kontextu tehdejších snah o reformu školy a současně se ptát, zda z nich vyplývají jisté závěry pro diskusi o současné reformě školství.

\section{KONTINUITA A DISKONTINUITA}

\section{REFORMNĚ-ŠKOLSKÉ DISKUSI}

Vznik Československa v roce 1918 znamenal v diskusi o školské reformě započaté již na konci 19. století zásadní přelom - zejména však politický a administrativní, nikoli až tak odborný. Z hlediska reformně-pedagogického se motivy školské reformy a představy o reformě výchovy výrazně nelišily, porovnáme-li diskusi před rokem 1918 a po roce 1918. Můžeme naopak říci, že základní rysy a problémy reformně-pedagogické diskuse, které krystalizovaly v středoevropském prostoru na přelomu
19. a 20. století, byly v poválečné Evropě zachovány a nadále rozvíjeny. Co však bylo jiné, byla očekávání, která byla s reformou školy a výchovy spojována $\mathrm{v}$ pedagogické i širší společenské veřejnosti. Programová kontinuita reformně-školské diskuse byla důležitá, nebot kultivovala tehdejší diskusi o reformě školy, dovolovala jí zamýšlet se nad reformně-školskými požadavky analyticky i s nadhledem. Rovněž v tehdejší politické a veřejné diskusi představovala reforma školy zásadní téma, i když společnost byla sociálně, politicky a národnostně značně různorodá.

Mưžeme se ptát, co „zachránilo“ českou meziválečnou diskusi o reformě školy před zjednodušenými pohledy přicházejícími z tábora tzv. kulturní kritiky a pranýřujícími ztrátu „vyšších ideálů klasického vzdělání“ na úkor „plytkosti“ utilitaristicky orientovaného modelu vzdělání. Můžeme se ptát, proč nepropadla česká diskuse pesimistickým směrům kritizujícím projekt moderní civilizace založený na osvícenském myšlenkovém a kulturním projektu, proč odolala hlasům z okruhu nacionalistických proudů brojících proti socialismu, ale i kosmopolitismu, modernímu světoobčanství, údajné slabosti humanistických ideálů důvěřujících $\mathrm{v}$ samostatnost, svobodu, ideály pravdy a tím i $\mathrm{v}$ kritičnost člověka vưči sobě sama a okolnímu světu. Domnívám se, že to byla právě kontinuita a založení, tedy tradice společenské a pedagogické diskuse, kterou si přinášela jako „rodinné stř́ibro“ česká reformně-školská diskuse po roce 1918 do samostatného Československa. Byla to zkušenost více než trriceti let intenzivní diskuse o reformě tzv. 
volné školy, vedená od devadesátých let 19. století mezi českým učitelstvem i odbornou pedagogickou veřejností, zakládající se na ideálech volnomyšlenkářského, liberálního, sociálně rovnoprávného, národního, ale i světoobčansky otevřeného společensko-reformačního hnutí (upozorňuji zejména na práce sociologa a pedagoga Břetislava Foustky, ale i na kritiku jisté uzavřenosti a národní omezenosti reformně-školských snah ze strany Rádlovy Revize pokrokových ideálù v národni škole).

Takové dědictví více než třiceti let svobodné, kritické reformně-školské diskuse polistopadové Československo nemělo. Dezorientace - společenská, politická, kulturní, školsko-programová - byla po roce 1989 značná. Společenská architektura „starého světa " byla označena jako nepoužitelná, pravidla "nového světa“ se rodila v devadesátých letech 20 . století bolestně, často byla obcházena a tím byl zpochybňován samotný půdorys „nového světa“. Jistota evropských hodnot vtělená do projektu evropské integrace nedokázala vyvážit rozkolísanost nového geopolitického uspořádání světa, nastupujících dopadů globální ekonomiky a nebývalé propojenosti světa díky moderním technologiím měnícím překotně rychle a radikálně sociální vazby člověka, ale i emociálně-sociální stabilitu a hodnotovou ukotvenost člověka v jeho okolním světě.

Meziválečná reformně-školská diskuse byla postavena před zkoušku odolat vábení totalitárních modelů společnosti slibujících životní jistotu, stálost, pořádek, překonání moderního pocitu odcizení člověka (Entfremdung), vytvoření sociálně harmonického, jasně uspořádaného a ideově pře- hledného světa, vytvoření rasově čistého, národně uzavřeného společenství, resp. internacionální komunistické fronty. Současná diskuse o reformě školy (nejen česká) musí uchránit kritický nadhled před silným populismem reagujícím na reálná nebezpečí daná dopady globální ekonomiky, hrozbou ekologického zkolabování světa, dopady extrémně nerovnoměrného rozložení světového bohatství mezi severem a jihem a důsledky lokálních válečných konfliktů přinášejících tlak na přesuny značného počtu obyvatelstva vykořeněného ze sociálních, kulturních a ekonomických vazeb jejich původního prostředí; válečných konfliktů, jež mohou snadno a rychle přerůst v konflikty závažnějšího dopadu.

Vidíme všichni, že svět se od devadesátých let 20. století rychle změnil, o to více je třeba nekapitulovat před otázkou, jakým směrem se pravděpodobně může svět ubírat, na jaké výzvy budou zréejmě muset odpovídat generace, které za deset či dvacet let budou opouštět školský systém, a jaké znalosti, hodnoty a príistupy $\mathrm{k}$ sobě sama, $\mathrm{k}$ druhému člověku a ke společenství jim pravděpodobně umožní nikoli nejlépe, ale zodpovědně řešit tyto výzvy. Česká reformně-školská diskuse je v tomto ohledu v nelehké situaci, nebot kontinuita svobodného uvažování nad cíli, směrem školské reformy byla radikálně přetržena a „vrženost“ do reformně-školského dění je znesnadňována četnými, mnohdy nepřehlednými, kuriózními a především permanentními reformními požadavky, které přicházejí ze strany nejrůznějších zájmových skupin, jimž stát přenechává, mnohdy nelogicky ochotně, vlastní prostor - at již dobrovolně, či jako důsledek vlastní neak- 
ceschopnosti dané nedostatečným fungováním státních institucí a přebujelé, mnohdy jen formálně fungující byrokracie.

\section{Hledají SE IDEJE, VĚdeCKÉ, FILOZOFICKÉ UKOTVENÍ \\ A OPODSTATNĚNí CÍLŮ \\ ŠKOLSKÉ REFORMY}

Představitelé meziválečného reformně-školského hnutí byli přesvědčeni, že východiska školské reformy - vnější i vnitřní - se musí opírat o vědecké zásady pedagogiky. Tím ovšem byl znovuobnoven zásadní spor již předválečného období - otázka utváření pedagogiky jako vědy. V českých zemích rakousko-uherské monarchie měl tento spor o to zajímavější podobu, že se na velmi malém intelektuálním prostoru scházely velmi odlišné pedagogicko-vědecké tradice, které byly dány národnostně (německé a české ukotvení pedagogiky).

Česká pedagogika jako věda shledávala od poslední třetiny 19. století jako nutnost „vymanit se" $\mathrm{z}$ německo-rakouské a herbartovské pedagogické tradice a primknula se především $\mathrm{k}$ Spencerovu pozitivistickému pojetí pedagogiky a Darwinově evoluční teorii. Dané ukotvení nacházíme jak u G. A. Lindnera, tak u Josefa Durdíka a především u Františka Krejčího, později částečně i u Františka Drtiny a zejména Otakara Kádnera, Cyrila Stejskala, Stanislava Velínského a zástupců psychotechniky. Zásadní bylo dané směrování pro Františka Čádu a pro vývoj české pedologické diskuse. Její význam pro programové nastavení meziválečné školské reformy nesmíme podce- ňovat. Proč? Jednak se ukazuje s ohledem na zahraniční výzkumy devadesátých let 20. století (zejména práce Belgičana Marca Depaepeho a německého pedagoga Petra Dudka) zásadní význam pedologie, resp. experimentální pedagogiky a experimentální psychologie pro utváření vědeckého základu a profilu pedagogiky a pro utváření tehdejšího reformně-školského programu.

Bylo to především samotné učitelstvo, které volalo při promýšlení reformních školských zásad po „datech“ a vědeckém základu reformně-školského směřování. Data měla dodat experimentální pedagogika či pedologie. Učitelstvo $\mathrm{v}$ mnoha zemích zakládalo pedologické a experimentálně-pedagogické ústavy, aby mohlo reformu školy postavit na skutečně vědecký základ. Věda a vědecký pokrok byly tehdy v mnoha reformně-školských kruzích synonymem pro úspěšnou realizaci reformy školy. Rychlý transfer myšlenek tzv. child study Stanleyho Halla z USA do Evropy vedl $\mathrm{k}$ rozvoji evropské pedologie a experimentální pedagogiky - zprvu v Německu, později ve Francii, Švýcarsku, ale i Belgii, Rusku (resp. Sovětském svazu), v Dolních Uhrách, (resp. Mad’arsku), či právě v českých zemích a později v meziválečném Československu. Experimentální pedagogika si vytvárela svůj vědecký svět - byly pořádány konference, pedologické kongresy, zakládány pedologické ústavy, laboratoře, vznikaly významné pedologické časopisy, knižnice pedologických statí a zástupci experimentální či empirické pedagogiky velmi rychle usilovali o habilitace a získání raádných profesur. Budoucnost pedagogické vědy se měla dle mnoha tehdejších pedagogů opí- 
rat právě o vysvětlování pedagogických jevů a formulování zákonitostí a vývojových zásad ve výchově a učení na úkor př́stupů zakládajících se na porozumění a interpretaci (erklären vs. verstehen).

Takzvaná filozofická pedagogika se $\mathrm{v}$ mnoha ohledech ocitla $\mathrm{v}$ defenzivě oproti expanzivnímu empirickému, experimentálnímu pojetí pedagogiky, oproti exaktnímu pohledu na výchovu zakládajícímu se na síle pojetí poznání a pravdy daného světem tehdejších přírodních věd. Vystavět pedagogiku na vědeckém základě znamenalo pro pedagogické pozitivisty, později pro pedology, založit pedagogickou teorii na výstupech experimentálního šetření s využitím výzbroje statistických metod. To vedlo pedagogiku $\mathrm{k}$ velmi interdisciplinárnímu dialogu s psychologií, utvárející se sociologií, ale i tehdejší eubiotikou, dále tzv. sociální hygienou, antropologií, ale i medicínou, biologií či ekonomií. Měritelnost, exaktnost, racionalizační př́stupy a eficience se staly pojmy ovládajícími diskusi jak o vědeckém utváření pedagogiky, tak o programu reformy školy. Je zřejmé, že se jednalo o pojmy a př́stupy, které byly nejdřive rozvíjeny $\mathrm{v}$ americké pedagogické a psychologické diskusi a stály do značné míry v kontrastu $\mathrm{k}$ „tradičnímu“ evropskému konceptu vzdělání (v českých zemích významně ovlivněného německou novohumanistickou koncepcí - Bildung), jenž byl v mnoha směrech stále ještě hluboce zakotven v diskurzu německé idealistické filozofie a pedagogiky. Lze předpokládat, že tzv. filozofická či duchovědně orientovaná pedagogika se nehodlala vzdát svého významného postavení a nechat se označit jako neprogresivní, nevědecká, metafyzická, spekulativní. V německé diskusi ustupuje od dvacátých let 20. století experimentální pedagogika do pozadí. Rovněž je známo, jak vygradoval spor o pojetí pedagogiky v české diskusi - zejména mezi Otokarem Chlupem a Václavem Př́íhodou (ale již i v pracích Jana Uhra či Josefa Hendricha). Je důležité si uvědomit, že tento spor vyvrcholil právě v otázce vědeckého či filozofického ukotvení reformně-školského programu, nikoli primárně $\mathrm{v}$ akademické diskusi o pojetí pedagogiky jako vědy.

Jak číst tento znak meziválečné reformně-školské diskuse - hledání filozofického a vědeckého základu školské reformy? Jak hodnotit tento spor o pojetí pedagogiky a pojetí školské reformy? Je možno se na něj podívat pozitivně. Nejednotnost $\mathrm{v}$ otázce ukotvení pedagogické vědy dynamizovala rovněž diskusi o pojetí školské meziválečné reformy a nenechávala ji ustrnout jen v jednom či druhém „tábořr“. Spor byl pro definování školského reformního programu produktivní. Na jedné straně podporoval experimentálně-pedagogický výzkum a na druhé straně vedl ke korigování mnoha jednostranných pohledů na reformu školy, zejména prrístupů daných racionalizačním hnutím a zásadami tzv. vědeckého a technokratického řízení společnosti (hnutí scientific management a taylorismus). Reflektujeme-li současnou diskusi o reformě školy, chybí jí daný spor. Je to samozřejmé. Pedagogika je etablovanou vědou, její postavení není zpochybňováno, má vypracovaný metodologický aparát a rozvíjí otevřeně pedagogickou teorii. Přesto je zřejmé, že vědecké spory o teoretické ukotvení pedagogiky, tj. teoreticko-koncepční soupeření, 
$\mathrm{k}$ rozvoji pedagogické praxe patří a pomáhají otevřeněji reflektovat reformně-školské otázky. Daný spor rovněž vyvažuje oba póly, jež jsou i v dnešní pedagogické vědecké diskusi zrrejmé.

Je otázkou, nakolik se př́i uvažování nad školskou reformou máme nechat vést širší reflexí cílů výchovy a vzdělávání (tedy tzv. filozofickou pedagogikou) a nakolik založit reformně-školské každodenní jednání na ověřených výstupech empirického pedagogického výzkumu. Dovoluji si konstatovat, že tento spor, který patří k základním tématům pedagogické diskuse, v kultivované odborné podobě potřebujeme a je otázkou, zdali jeho absence nemůže být pro definování východisek současné školské reformy kontraproduktivní. V jistém ohledu totiž může vést ke stagnaci rozvoje vědeckého potenciálu pedagogiky a paradoxně i ke stagnaci empirického pedagogického výzkumu. I tak lze dle mého pohledu číst požadavek komise expertů vypracovávající Strategii 2030, která upozorňuje na přehodnocení témat současného pedagogického výzkumu takovým směrem, aby poskytoval data pro kompetentní rozhodování ve věcech školské reformy a aby zpracovával témata, která napomohou diskusi o reformě českého školství.

\section{Př́ REFORMĚ ŠKOLY ZÁLEŽí}

NA VŠECH AKTÉRECH A VZORECH

- DOMÁCÍCH A ZEJMÉNA

ZAHRANIČNÍCH

Školská meziválečná reforma si vedle filozofického, vědeckého ukotvení žádala akceschopnost, tedy obhajování, prosazování a realizaci reformního programu u širokého spektra aktérů. $\mathrm{V}$ roce 1919 byl založen Pedagogický ústav J. A. Komenského, který měl za úkol tematizovat požadavky školské reformy $\mathrm{v}$ širších vztazích a mimo jiné i v určitém filozofickém kontextu, dále měl opřít reformu školy o výsledky pedagogického, pedopsychologického výzkumu a měl promýšlet reformu školství v ČSR s ohledem na zkušenosti evropské či zámořské, zejména americké. Ústav byl poradním orgánem ministerstva školství a národní osvěty (MŠANO), konal ankety k aktuálním otázkám školské reformy a reformy střední školy. Tyto úkoly naplňoval Ústav, $\mathrm{v}$ jehož čele stanula mimořádná osobnost pedagogické vědy Otakar Kádner (1870-1936), řádně avšak s problémy, nebot' MŠANO nevytvořilo podmínky pro vědeckou práci ohledně reformy školství, jaké slibovalo. To vedlo k odstoupení $\mathrm{O}$. Kádnera $\mathrm{z}$ čela této instituce ( $\mathrm{v}$ roce 1922) a k celkovému oslabení a zúžení přidělených úkolů až nakonec ke zrušení Ústavu v roce 1925.

Zásadní roli v diskusi o československé reformě školy však sehrály učitelské spolky. Reforma školství představovala jedno z centrálních témat na sjezdu československého učitelstva $\mathrm{v}$ roce 1920 v Praze. Po něm následovalo sjednocení učitelstva v Československé obci učitelské (dále ČOU), která měla překonat programovou roztřríštěnost československého učitelstva a podpořit jeho akceschopnost v dosahování základních požadavků školské reformě a reformě učitelského 
vzdělávání. ${ }^{2}$ I když sjednocení učitelstva zažilo v třicátých letech 20 . století ještě značné změny, je nutné zdůraznit, že role ČOU v reformě školy byla značná. ČOU založila v roce 1921vlastní výzkumný Ústav pro experimentální pedagogiku a psychologii vedený O. Chlupem, O. Kádnerem a pak V. Pŕíhodou. Ústav poskytoval vědecké podklady reformě školy a zároveň byl stěžejní pro reformu učitelského vzdělání - měl učitele seznamovat $s$ výstupy výzkumu, ale i je do výzkumu vtahovat a naučit je výzkumně pracovat. Zásadní dále bylo založení svépomocné organizace dalšího vzdělávání učitelstva - Školy vysokých studií pedagogických (ŠVSP) v roce 1921, kde reformně naladěné učitelstvo bylo hlouběji seznamováno $\mathrm{v}$ přednáškách a diskusích $s$ moderními filozofickými, pedagogickými a psychologickými směry, s výsledky experimentálně-pedagogického výzkumu a $\mathrm{v}$ rámci studijních cest učitelstva $s$ př́klady zahraničních modelů školské reformy. Podstatnější ovšem bylo, že $\mathrm{v}$ rámci ŠVSP krystalizoval reformně-školský program na základě společných diskusí učitelů a pedagogických odborníků. ŠVSP jako organizace učitelstva se tak stala organizací utvářející reformně-školský program, a to na základě vědeckých poznatků, dat, ve spolupráci $s$ akademickou obcí a ve vztazích se školskou správou - inspekcí a ministerstvem školství a národní osvěty.

Taková symbióza byla v Evropě ojedinělá, jak ukazují výzkumy $\mathrm{k}$ problematice reformy školy v evropských státech. Čes- ký př́klad byl mimořádný, nebot výsledky diskuse o reformě školy a o moderních pedagogických směrech se díky činnosti ŠVSP a sítování přednášejících na ŠVSP dostávaly rovněž do sféry některých učitelských ústavů a ovlivňovaly budoucí generace učitelů. Reformně-školský program, zejména po roce 1928 , byl výsledkem diskuse $\mathrm{v}$ učitelských kruzích, vzešel „zespodu“ a učitelstvo si jeho povolení, přijetí a prosazení na ministerstvu školství a národní osvěty samo „vynutilo“. Jako ke „svému dítěti“ se $\mathrm{k}$ němu také chovalo - reformní zásady plánovitě ověřovalo, průběžně vyhodnocovalo a prosazovalo jako součást osnov. Přitom se nejednalo o program složený $\mathrm{z}$ nekoordinovaných zkušeností školských reformátorů, nýbrž o koncepční program, který byl výsledkem spolupráce pedagogické vědy, vyspělé pedagogické akademické diskuse a bohatých zahraničních zkušeností ze studijních cest, reflektovaných a vyhodnocovaných v rámci odborných textů i seminářů.

Již př́ed rokem 1914 zaujímala v časopise Český učitel důležité místo část o slovanském školství, po roce 1918 ustupují zprávy z Jugoslávie, Bulharska, Polska či Sovětského svazu a na významu získaly zprávy o severském školství, o školství v Nizozemí, Francii, Belgii, Švýcarsku, Velké Británii, o školách Montessori a rovněž o americkém školství. Český učitel se mohl bliže a konkrétně seznámit s reformní prací Decrolyho, Ferriéra či winnetským plánem. České učitelstvo bylo zpravováno o činnosti hnutí nových škol,

${ }^{2}$ Více $\mathrm{k}$ roli Československé obce učitelské ve školské reformě i v reformě učitelské přípravy v meziválečném období srov. Kasperová, 2018. 
o práci Ligy pro novou výchovu (New Education Fellowship, NEF) a o aktivitách jejích představitelů či o jednotlivých konferencích této mezinárodní reformně-pedagogické učitelské organizace. Těchto konferencí se české učitelstvo samo zúčastňovalo a o akcích vždy referovalo (nejvýznamnější a časopisecky nejtematizovanější byla účast Františka Bakuleho v Heidelberku v roce 1925 a v roce 1927 v Locarnu, kde byly rozšriřeny odborné vztahy s Ferriérem či Decrolym).

Zprávy o zahraničních modelech školské reformy byly intenzivnější i díky vydávání časopisu Nové školy Otokarem Chlupem v roce 1926 v rámci činnosti brněnské Společnosti Nových škol, jež byla československou pobočkou reformního hnutí $\mathrm{v}$ rámci světové Ligy pro novou výchovu (časopis vycházel v letech 1926-1935). Podobně jako zprávy z ciziny a ze zahraničních cest sehrály důležitou roli $\mathrm{v}$ sekci Literatura $\mathrm{v}$ učitelských časopisech recenze a analýzy vybraných zahraničních knih, které byly zápisky o dění reformních škol či teoreticky reflektovaly východiska a zkušenosti pokusné práce či nových směrů ve výchově a v pedopsychologii. Významné místo zde měl pracovník Pedagogického útavu J. A. Komenského Emanuel Lippert, který ve Školských reformách ve dvacátých letech 20.století intenzivně a podrobně informoval o americké školské metodice. Důležitou roli v tomto ohledu sehrála i knihovna Československého pedagogického ústavu J. A. Komenského. O jejích prírůstcích bylo učitelstvo zpravováno, a jak je ze zpráv patrno, knihovní fond týkající se mimo jiné publikací zahraničních reformních pedagogů se rychle rozšiřoval a byl velmi kvalitní. To se pak odráželo v hlubších analytických recen- zích těchto publikací v českých učitelských časopisech.

Do češtiny byly rovněž překládány knihy představitelů reformní pedagogiky. Mezi léty 1925 a 1935 vyšly v překladu upravené knihy Adolpha Ferriéra, Marie Montessori, Ovida Decrolyho či Edouarda Claparéda. Literatura $\mathrm{k}$ theosofické pedagogice byla bohatší. Již v roce 1907 byla $v$ rámci činnosti České theosofické společnosti vydána kniha Rudolfa Steinera Podstata člověka a výchova dètská s hlediska duchovni védy, v roce 1910 vyšla Steinerova Theosofie a v roce 1919 jeho přednáška Výchova dètská. V roce 1923 podniklo české učitelstvo cestu do švýcarského Dornachu, centra Steinerovy antroposofie, kde se účastnilo několika jeho přednášek.

Samostatnou kapitolou však byl vliv americké pedagogiky a celkově amerického pohledu na společnost. Zásadní byl dlouhodobý pobyt Václava Př́hody na univerzitě v Chicagu a na Teachers College v New Yorku v letech 1922-1926, ale i pobyty dalších významných představitelů české pedagogiky především na Teachers College v New Yorku - Karel Velemínský (1912 až 1913), Jan Uher (1926), František Pražák (1930-1931), Stanislav Velinský (1923 až 1924), Stanislav Vrána (1927-1928), Břetislav Foustka (1930-1931), Otakar Matoušek (1929-1930).

Díky pozitivismu zakořenily $\mathrm{v}$ českém pedagogickém myšlení střízlivost a věcnost v oblasti poznání, důvěra ve vědecké poznání světa. Př́iklon ke světu dítěte znamenal i př́klon $\mathrm{k}$ procesům učení a poznávání žáka - prŕklon ke zkušenosti a její roli a významu v procesu poznávání. I když 
nevznikly v české filozofické tradici četné odborné studie analyzující východiska amerického pragmatismu, nemůžeme říci, že by české filozofické myšlení nesledovalo vývoj v USA. Americký pragmatismus jako jeden z proudů moderní filozofie reflektoval profesor filozofie na Univerzitě Karlově v Praze František Krejčí (1858-1934; Filosofie poslednich let pred válkou, 1918). Dále se reflexi moderních filozofických proudů věnoval profesor Univerzity Komenského v Bratislavě Josef Tvrdý (1877-1942; Nová filosofie, 1932; Prưvodce dějinami evropské filozofie, 1932; Úvod do filosofie, 1926). Samostatnou analýzu pragmatismu předložil profesor Univerzity Karlovy a středoškolský učitel Karel Vorovka (1879-1929). S kořeny americké filozofie přelomu 19. a 20. století byli seznamováni studenti pražské filozofické fakulty rovněž v přednáškách Františka Č́dy či Břetislava Foustky, jak jsem dohledal v pozůstalosti V. Př́hody.

Ještě více byla sledována americká pedagogická a psychologická diskuse a především americká škola, jak ukazuje citát představitele Svazu učitelstva československého a ústředního inspektora Vojty Beneše, bratra druhého československého prezidenta a rovněž významného představitele spolupráce českých učitelů $s$ americkými krajanskými spolky. Vojta Beneš napomohl politické akci Masarykově na jaře roku 1918 ve Spojených státech amerických a po celé období první světové války napomáhal v USA prosazovat myšlenku samostatného Československa. V roce 1921 ve stati Obrázky z amerického školství Vojta Beneš prohlašuje: „Bylo-li devatenácté století ve výchově stoletím německé pedagogiky, bude jistě století dvacáté náležeti zemi dítěte -
Americe. Míním tím přirozeně Spojené státy americké. Jejich výchova je vědecká na rozdíl od učené školy německé $\mathrm{v}$ minulém století. ... Amerika vytvořila školu činné práce, vůle, charakteru, inteligence vůbec" (Beneš, 1928, s. 32-33). Vojta Beneš pak vyzdvihuje význam G. Stanleyho Halla, Williama Jamese a Johna Deweyeho jako osobnosti, ,jimiž vyvrcholilo snažení o demokratickou školu americkou nejvýše“ (tamtéž, s. 3).

Jestliže před válkou česká pedagogická diskuse čerpala z amerických studií pro rozvoj české pedologie a experimentální pedagogiky, potom po válce se jednalo o velmi intenzivní kontakt jak s americkým behaviorismem, tak i Jamesovým pragmatismem a Deweyeho instrumentalismem. Dokládají to nejen dlouhodobé a koncepční studijní cesty českých pedagogů do USA, ale i mnohé články českého učitelstva v Českém učiteli, Školských reformách, Tvorivé skole i dalších pedagogických časopisech. Spojené státy přes všechny politicko-společenské rozpory platily $\mathrm{v}$ očích významné části českého učitelstva za př́iklad progresivní, moderní společnosti, za společnost pokroku a vědy využívající sílu techniky a vědeckého řízení, za společnost, která kladla důraz na jednání a zodpovědnost jedince a na roli svobodného jedince ve společnosti. Jestliže anglosaský pozitivismus, zejména Spencerův, pomohl českému pedagogickému myšlení na konci 19. století odmítnout německou filozofickou tradici, potom americké pedagogické a psychologické myšlení počátku 20. století sehrálo značnou roli př̀i hledání pedagogických vzorů pro nově vzniklé Československo. Avšak podobně jako u jiných zahraničních vzorů nejednalo se ani v případě amerického vlivu o zjednodušený jednostran- 
ný transfer. Vyspělost českého pedagogického myšlení umožňovala číst americký vliv na pozadí vlastní domácí tradice a osobitě zpracovávat americké podněty pro nové směrování českého pedagogického myšlení a reformu školy. Vyspělost a kritičnost české pedagogické diskuse byla tak silná, že nebylo nutné „opisovat" cizí vzory - americké, či jiné. Meziválečná reformně-školská diskuse významně profitovala ze své otevřenosti, intenzivního a prírozeného kontaktu s vyspělou částí světové reformně-školské diskuse. Její východiska dokázala česká pedagogika kriticky číst a produktivně přetavit a využít $\mathrm{v}$ rámci domácího reformně-pedagogického hnutí.

Ukazuje se, že právě otevřenost zahraničním pedagogickým impulzům je pro reformu školy významným faktorem vedoucím $\mathrm{k}$ propracovanému reformně-školskému programu. Chtělo by se říci, že nikdy není dost zahraničních zkušeností, pokud chceme reformovat vlastní školství. Zahraniční zkušenost přináśí odstup a umožňuje podívat se na vlastní tradici, vlastní východiska „zvnějšku“", umožňuje „poodstoupit“ a zároveň nevystoupit z vlastní struktury reformně-školského uvažování. V tomto ohledu bychom měli usilovat i v rámci současných strategií $\mathrm{k}$ reformě školy o hlubší poznání zahraničních pohledů na adresu reformy výchovy a vzdělávání. Toho lze docílit jak studiem zahraniční literatury, tak zejména dostatečnou zahraniční mobilitou a konkrétní diskusí se zahraničními odborníky. Mnohé aktuálně vyhlašované evropské výzvy nám $\mathrm{k}$ tomu napomáhají, jejich řešení je však mnohdy značně byrokratické.

\section{ZÁVĚR ${ }^{3}$}

1. Jak se ukazuje na př́kladu analýzy meziválečné pedagogické diskuse o reformě školy, vyžaduje reformní dění program, který bude odborně, vědecky podložen, filozoficky ukotven, ale i rozpracován samotným učitelstvem. Tento program musí být v souladu se širší pedagogickou diskusí pěstovanou $\mathrm{v}$ aktivních platformách učitelstva - princip kontinuity. $\mathrm{Na}$ druhou stranu musí představovat jistý „řez“ $\mathrm{k}$ novému cíli - princip diskontinuity.

2. Školská reforma, pokud má zasáhnout školství a vyvolat změny, vyžaduje aktivní aktéry, především učitelstvo. Pro úspěch reformy je podstatné, aby učitelé (nejen ti, kteří aktivně usilují o reformu) stáli v symbióze $s$ akademickým prostředím a dostávalo se jim podpory státních orgánů (ministerstva školství a školské inspekce).

3. Program školské reformy musí gradovat v prostředí a kontextu mezinárodní pedagogické diskuse. Nemůže být jen národní, ani jen kosmopolitní a světu otevřený. Školsko-reformní úsilí musí rozumět specifičnostem národním v nadnárodní otevřenosti.

4. Školská reforma musí být záležitostí pedagogické vědy (rozumu), ale i pedagogického srdce (W. Brezinka). Musí řešit především pedagogické, didaktické a pedagogicko-psychologické otázky procesů učení, problematiky vzdělávání a výchovy. Školská reforma nesmí být výhradně záležitostí školské byrokracie, ale školské praxe.

\footnotetext{
${ }^{3}$ Následující závěry nejsou myšleny normativně, nýbrž jako shrnující závěr předcházející analýzy. Za toto zpřesnění děkuji diskusi s dr. D. Dvořákem.
} 


\section{Literatura}

Beneš, V. (1928). Obrázky z amerického školství. In Beneš, V. O lepš̌i svět. Praha: Svět národního osvobození.

Kasper, T., \& Kasperová, D. (v tisku). Nová škola v meziválečném Československu ve Zlinè ideje, aktéri, mista. Praha: Academia.

Kasper, T., Kasperová, D., \& Pánková, M. (2018). Národni školstvi za prvni československé republiky. Praha: Academia.

Kasperová, D. (2018). Československá obec učitelská v kontextu reformy vzdélávání učitelů (ŠVSP) a reformy školy. Praha: Academia.

doc. PhDr. Tomáš Kasper, Ph.D.

Technická univerzita v Liberci, Fakulta prírodovédnè-humanitní a pedagogická, katedra pedagogiky a psychologie; email: tomas.kasper@tul.cz 